\title{
Impediments to Linking Forest Islands to Central Forest Spine in Johor, Malaysia
}

\author{
Agkillah Maniam and Kuppusamy Singaravelloo
}

\begin{abstract}
The National Physical Plan identified the dire need to reenact the links between isolated forest islands to the central forest spine to protect biodiversity of Peninsular Malaysia's wealth of ecology. With that the peninsula has had its own Central Forest Spine as a milestone documentation aimed at bringing together various players towards achieving the goal, including interplay between state and federal agencies. Despite having documented and approved by the cabinet some years back, little has been achieved so far. While there are some activities that have taken place, the paper explores the predicaments and problems faced in achieving the said goal. Interviews with the senior officers at the respective agencies were the major source of information on this exploratory research. The paper finds there needs to be more concerted efforts by all parties and as such, financial and coordination of plans and activities form the key recommendation of this paper.
\end{abstract}

Index Terms-Forest administration, central forest spine (CFS), forest fragmentations, administrative action in recreating links and institutional roles.

\section{INTRODUCTION}

In Malaysia, forest covers has reduced rapidly due to many development projects [1] and intense agricultural activities [2]. Historically, [3] recorded that Malaysia had forest canopy almost to its entirety while in 2009 this figure stood at $55.8 \%$ [4]. Forest fragmentation is considered as primary concern in biodiversity conservation [5]. Of late, there are increasing demands that fragmented forests should be conserved. The government called for a national effort to reinstate the connectivity of these forests under the Central Forest Spine (CFS) establishment to protect water catchments, prevent landslides and floods and to conserve biodiversity [6]. The government intervention was crucial to link the forest islands to the spine but this effort is still not showing desirable results. This paper attempts to express the successes and problems faced by the initiative to link forest islands to the central forest spine, especially by examining the federal-state relationship and the will of the state government in introducing the effort.

\section{Methodology}

In depth, face to face, semi-structured interviews and discussions were carried out with officers from various federal and state government and their agencies and also key

Manuscript received August 22, 2013; revised October 25, 2013.

Agkillah Maniam and Kuppusamy Singaravelloo are with the Department of Administrative Studies and Politics, Faculty of Economics and Administration, University of Malaya, 50603 Kuala Lumpur (e-mail: agkillah@um.edu.my, kuppusamy_s@um.edu.my). non-governmental organizations. The secondary data collection included information from books, reports, published and unpublished sources from government department and also internet search. Interviews were conducted with the following:

- Biodiversity and Forest Management Division, Ministry of Natural Resources and Environment (MNRE), Putrajaya

- Central Forest Spine Section, Forestry Department of Peninsular Malaysia (FDPM), Putrajaya

- Ecotourism Division, Department of Wildlife and National Parks of Peninsular Malaysia (PERHILITAN), Kuala Lumpur

- Town and Country Planning Department (TCPD), Kuala Lumpur

- Planning and Management Unit, State Forestry Department of Johor (FDJ), Kota Iskandar

- Department of Wildlife and National Parks of Johor (PERHILITANJ), Kota Iskandar

- National Parks Corporation of Johor (NPCJ), Kota Iskandar

- Department of Land and Mines, Johor (DLMJ), Kota Iskandar

- State Economic Planning Unit of Johor (EPUJ), Kota Iskandar

- Conservation Department, Malaysian Nature Society (MNS), Kuala Lumpur

- $\quad$ TRAFFIC International, Kuala Lumpur

\section{CONTEXTUALIZING THE CONUNDRUM}

In Malaysia, government and economics are two main aspects that drive the forestry sector. The federal government legislate policies pertaining to governing forest by engaging National Land Code through two important apex councils; National Land Council and National Forest Council, while the state governments have autonomy over forest and land. The government system in Malaysia operates on a three tier levels, i.e. the federal government, state and lastly local governments as prescribed in the Federal Constitution. The jurisdictions of the Federal and the State governments are guided by three lists; the Federation List, the State List and the Concurrent List. The federal government is administered through 25 ministries and those who work on forests are MNRE, Ministry of Energy, Green Technology and Water, Ministry of Rural and Regional Development, Ministry of Plantation Industries and Commodities and Ministry of Works. Economic Planning Unit (EPU) under the Prime Minister's Department is the overarching driver of economic planning and disperses its authority over other agencies, 
ministries, and bodies after policies are decided upon.

Malaysia's population stands at almost 27.5 million people over its terrain of about 330,000 km2 [7]. Forests in Malaysia consist of lowland dipterocarp forest, hill dipterocarp forest, upper hill dipterocarp forest, oak-laurel forest, montane ericaceous forest, peat swamp forest and mangrove forest, freshwater swamp forest, heath forest, forest on limestone and forest on quartz ridges. The National Forestry Act 1984 categorized forests into eleven classes based on functions which are production forest, virgin jungle reserved forest, forest sanctuary for wildlife, water catchments forest, soil protection forest, education forest, amenity forest, research forest, soil reclamation forest, flood control forest, and forest for federal purposes. In 2003, FDPM allowed forest areas to be categorized by its forest contents, land productivity, climate, botanic aspects and soil [8]. Nonetheless, Malaysia is still listed as one of the 12 mega-diverse nations across the globe due to its rich biodiversity even though Malaysia faces an annual deforestation rate of $0.7 \%$, beginning with 9.5 million hectares in 1954 to 5.9 million hectares in 2008 [7]. Multi-functions of forest justified its protection and conservation to equally balancing development, urbanization and modernization. Malaysia's tropical rainforests houses about 70 percent of world's flora and fauna species, and 200 trees species on every acre in comparison to other types of forests [9]. Forests contribute to carbon sink, serve as water catchment areas and oxygen, and generate revenues for the nation. Deforestation in a huge scale causes an imbalance in water equilibrium which in turn affects climatic changes [10]. In Malaysia, forests are protected to safeguard water resources [11]. Upon deforestation, wildlife mammals lose their habitats and eventually disappear as they are unable to survive outside their normal cycle as the residual forested areas are unable to refuge these animals leading to some of the species being enlisted as extinct or endangered, including Sumatran tigers, Sumatran rhinoceros, Sumatran and Bornean orangutans, and Asian elephants [9]. On this note, some 170 endemic species from the flowering plants have become extinct since 1948 while 143 animal species are facing similar threats due to reasons such as logging, hunting, trade, habitat destruction and forest conversion [12]. Opening of new areas increased chances of locating and hunting for wildlife which indirectly has also increased the illegal wildlife trade.

MNRE is responsible for overseeing the administration of forests in Malaysia, under which implementation agencies such as DLMJ, Department of Survey \& Mapping Malaysia and National Institute of Land and Survey, FDPM, FRIM, Minerals and Geoscience Department Malaysia, Department of Environment (JAS) and PERHILITAN. MNRE is accountable for management of forest, irrigation and drainage, wildlife, mineral, environmental conservation, marine parks, land and its surveying, and processing mapping. Ministry of Primary Industries and Commodities is responsible for developing manufacturing, $R \& D$ and marketing of commodities inclusive of timber besides others such as palm oil, copper, tobacco, pineapple and tin. TCPD is the governing agency for land use and physical planning at both national and states levels.

There are different legislations which fall under the jurisdiction of the federation, peninsular states, Sabah and Sarawak. The Ninth Schedule in the Federal Constitution underlines responsibilities that fall under the Federal, State and the Concurrent List. The legislations for wildlife protection and addressing illegal trades are made stricter with the new Wildlife Conservation Bill passed by the Parliament in 2010 [13]. In 1978, National Forestry Act, was formulated to provide for the administration, management and conservation of forests and forestry development within states [14] was introduced at the federal level [15]. Forest lands are gazetted as Permanent Reserve Forest through two major categories (a) no logging allowed due to scientific research and recreational reasons, or for preservation of water catchment areas, and (b) production forests.

Land use patterns in Malaysia were influenced by its economic activities which caused widening of plantations, commercial logging increased deforestation [16]. Oil palm plantation has been named the main commodity that causes deforestation in Malaysia [17]. On the other hand, the land-use patterns of oil palm plantations that increased from 55,000 hectares in 1970 to 5.3 million hectares in 2010 which takes up about 14 percent of Malaysian lands [18]. Oil palm plantations had been accused mainly by the European non-governmental organizations to be the major contributors to forest fragmentations [19]. Industrialization has caused extensive land use in Penang, Perak, Selangor and Malacca [20]. Land use patterns and found that urban areas expanded up to 159 percent from 1989 to 1999 [21]. Only $373.8 \mathrm{~km} 2$ of urban land were used in 1989 and this increased to $966.5 \mathrm{~km} 2$ in 1999 accounting for the new developed urban areas such as Kuala Lumpur International Airport, Nilai new town, Putrajaya, Bangi, Bandar Tun Hussein Onn, Klang, Rawang and Sungai Buloh among the many. The requirements to carry out Environmental Impact Assessment in large scale development still have many loop holes and the requirement of this federal law is not applicable for the states of Sabah and Sarawak.

The forest in Malaysia is administered mainly by MNRE. However, there are many complementary agencies like the Forest Research Institute Malaysia (FRIM), FDPM, PERHILITAN, TCPD and DLMJ. All except FRIM also administer at the state level. CFS (Fig. 1) distinguishes fundamental ecological roles of the forests which would contribute to the sustainability of the ecosystem in the country [6]. The National Physical Plan (NPP1) supports the present economic plan with spatial planning in the five-year periodical Malaysia development plans [6]. CFS is essentially the backbone of the environmentally-sensitive area network identified by NPP1 and would form a vital component of the revised NPP1 into National Physical Plan 2 (NPP2) [6]. Serving as a blueprint used for spatial planning in Peninsular Malaysia, CFS aspires to conserve interconnected forests which also serve as habitat for tigers. This further supports the National Tiger Action Plan (2008-2020) which aims to establish a wholesome but intensive and feasible protection plan that outlines precise actions that is to be carried out in the first phase (2008-2015) [22]. The remaining pieces of fragmented forests were forced to be coordinated for connection and protection of manyimportant aspects of the forest such as the water 
catchment as well as a natural solution for landslides, floods mitigation and biodiversity conservation [6]. CFS spreads across eight states in Peninsular Malaysia: Kedah, Perak, Kelantan, Terengganu, Johor, Pahang, Selangor and Negeri Sembilan and consists of four major forest complexes; Titiwangsa Range - Bintang Range - Nakawan Range, National Park - Timur Range, Southeast Pahang, Chini and Bera Wetlands, and Endau Rompin National Park - Kluang Wildlife Reserve [23]. It engages many agencies in its implementation as different agencies are experts in their own fields. The overall implementation framework of CFS has four stages; policymaking, planning, implementation and monitoring.

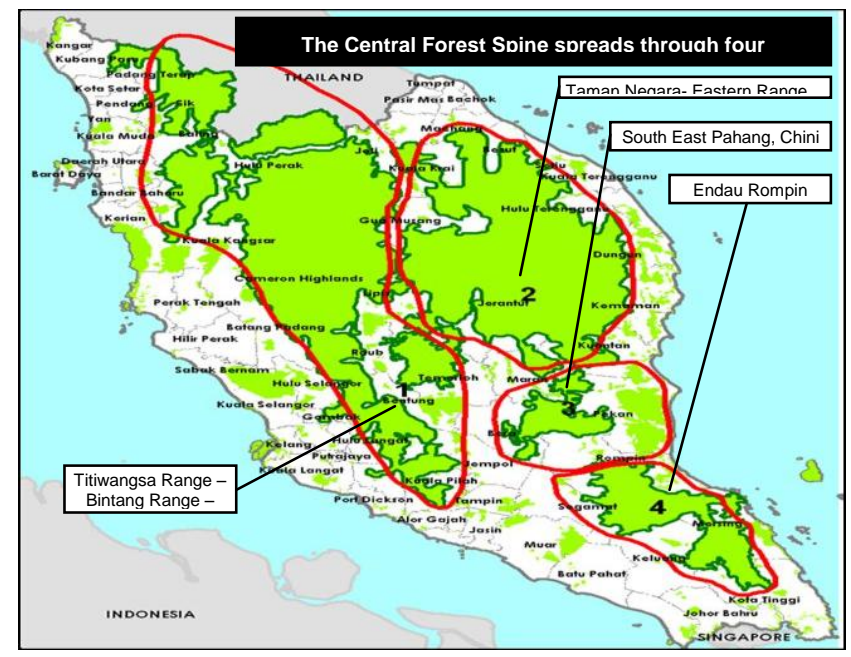

Source: Jabatan Perancang Bandar dan Desa Semenanjung Malaysia (2010).

Fig. 1. Central forest spine, Malaysia.

The state of Johor where this study was carried out is a state that lies at the southern tip of Malaysia (and Asia) has attracted the attention of government for intense development as the Southern Corridor emerging as a competitor to Malaysia's friendly rival, Singapore. The forested areas in this state are governed by FDJ which is an extension of federal FDPM. About 30 percent $(563,879$ hectares) of the total land in Johor of about 1,898,629 hectares is forested [24]. This figure also includes 351,711 hectares of Permanent Forest Reserves under the National Forestry Act 1984. This state is vital as it treasures many priceless and valuable components of the nature. Johor accounts for five national parks with a total area of more than 700 square kilometers besides other small pockets of forests which include National Parks of Endau-Rompin, Gunung Ledang, Tanjung Piai, Pulau Kukup, Johor Kepulauan Mersing, and ForestReserves at Gunung Pulai, Gunung Arong, Gunung Lambak, Gunung Belumut and Gunung Panti. FDJ is headed by the Forestry Director of Johor State supported by a Deputy and three departments; Forest Operations, District Forest Office and Forest Development Department. Just like other states, Johor has the wildlife agency belonging to the state which is responsible over the wildlife known as PERHILITANJ and the state national parks corporation, NPCJ. For states in Malaysia including Johor, forests are managed to fund the state's socio-economic necessities [25].

Sungai Mas forest, which is not only a cushion to the
Endau Rompin National Park but also an important habitat for wildlife, was cleared with intention of establishing a rubber estate [6]. In addition, the Sungai Mas forest is one of the essential areas in the Endau Rompin - Endau Kluang Forest which is included in the plan to be re-connected to the Endau - Kota Tinggi Forest as part of the Malaysia's CFS [6]. Besides, Johoreans would be facing more human-wildlife conflicts especially with elephants in districts like Segamat, Mersing and Kota Tinggi which are Johor's northern and eastern areas [26]. Johor also has a long history of human-wildlife conflicts with elephants, rhinoceroses and hippopotamuses since the 1980s due to the higher rate of forest conversions into land for agriculture and human settlement [26]. The state's wildlife department wing, PERHILITANJ, which has spent RM 6.5 million between 1990 and 2000 for the efforts of relocating elephants to the Endau-Rompin National Park, now dreads human-tiger conflicts to escalate based on unpublished wildlife assessment results [26]. The same source also reported that forest like Lenggor, Panti and Ulu Sedili are among the crucial tiger habitats besides Endau - Kota Tinggi Wildlife Reserve. Orang Kanaq is a group of indigenous people who live around the Kota Tinggi area, are well-known for their skills in collecting forest produces on ancestral land still remains an important component to them [27]. The study by [27] concluded that this group of indigenous people is already facing the edge due to rapid development that has affected them. As such, any drastic change in land use around this area would cause a major socio-economic impact on the indigenous people.

The Environmentally Sensitive Areas (ESAs) were preserved and conserved through a plan; Central Forest Spine (CFS) which was developed by engaging and consulting related agencies such as the MNRE, FDPM, PERHILITAN, Drainage and Irrigation Department (DID), PWD, Department of Land and Mines, and others. CFS was presented to the Parliament and duly accepted in April 2011. A National Steering Committee has been set up at the federal level consisting of MNRE as the chair and representatives from all the related agencies such as FDPM, PERHILITAN, FDJ, PERHILITANJ, TCPD and EPUJ. This committee aims to navigate and provide guidance to the involved states while initiating to set up a Technical Committee at the State level. However, the suggestion contained in CFS cannot be forced upon the eight states as the authority over land lies with the State government. CFS is taken only as a guideline and degree of acceptance by states may vary based on the federal-state relationship. Currently, there is no unit to coordinate, steer or enforce the ideas of CFS at state levels and there is no cap on production forest or forest plantations.

\section{FRAGMENTED AREAS, FACTORS AND IMPACTS}

The four main fragmented areas in the block of 'green heart' of Peninsular Malaysia are the Titiwangsa Range-Bintang Range-Nakawan Range, National Park-West Range, Pahang Tenggara-Chini-Bera Wetlands, and Endau Rompin National Park-Kluang Wildlife Sanctuary. In total, there are 17 primary links between two large forested areas and 13 secondary linkages which appear 
between two smaller islands of forests. In an area near Kampung Punan, the primary link is almost broken due to pre-approved latex-timber-clone plantation project since the plan has already been set into place. Numerous NGOs have tried to oppose to this but the State has not found a solution to it as it has to balance revenue development, and conservation.

The factors contributing to forest fragmentation are development for economy, building of roads and opening of land along the sides such as the North-South Highway, establishing housing areas, and opening of lands for plantations such as Ladang Mados. There are numerous indigenous settlements such as at Kampung Punan, Kampung Tewowoh, Kampung Pengkalan Bukit, Kampung Sungai Tuba, Kampung Sungai Peroh, Kampung Kenangan, Kampung Tanjung Tuan, Kampung Tanah Abang, Kampung Peta, Kampung Puchor, Kampung Puciut and Kampung Berasau. There are also two other major factors that influence the state governments in its drive against conservation, being (i) market prices on commodities have become a significant factor for the state governments to allow development on their forested lands and, (ii) lack of political will to retain forest cover.

There are three categories of forest impacts; namely social, environmental and economic. The most common is the social impact which is mainly human-wildlife conflicts. Nonetheless, an impact on one of the three areas exerts a domino effect on the other two. As an example, the crops in a developed plantation are destroyed by a herd of elephants as the plantation is established on their usual crossing path and may possibly harm the lives of the plantation workers. The destruction of the crops does not only affect the plantation owner and his employees socially but also economically where they have to re-invest or repair the damage done to the surroundings and people, if any. If the elephants are trans-located to a different area, other biological aspects need to be studied. As elephants are good seed dispersal agents for Machang trees, when trans-located, may cause a disturbance in the Machang tree population and would further face threat due to the absence of seed-dispersal agents. Parallel to this, the Head of Conservation Department of the Malaysian Nature Society (MNS) admits during an interview that forest fragmentations may cause a larger predator group to be stranded on an area which has lesser prey group. This distortion exposes the prey group to face the danger of being wiped out in numbers and further causing environmental imbalance. If this scenario is left unattended, the high biodiversity levels of the country would be lost rapidly and Malaysia would face many other related issues. These confirm the opinions of the officer from NPCJ as to the domino effects of social, economic and environmental impact.

\section{CONCERTED Role IN LiNKING FRAGMENTED AREAS AND OVERCOMING FRAGMENTATION}

As agreed to by MNRE, CFS is managed by them at the federal level and anchored by FDPM as the Secretariat that will have to work hand-in-hand with other agencies such as PERHILITAN, TCPD, PWD, DID, Land and Mines Department, and national NGOs. According to officers from
FDPM and PERHILITAN, in the case of Johor, the EPUJ must function as the chair at the state level and the Technical Committee must join forces with agencies such as PERHILITANJ, NPCJ, TCPDJ, PWDJ, DIDJ, DLMJ, local authorities and NGOs. According to the officers from the MNRE and FDPM, CFS is to be incorporated into the State Structure Plan by JPBD with the assistance of the State Secretariat of Johor. The FDJ takes upon the roles of being the secretariat at the state level and is a member of the Technical Committee. The NPCJ supports the mechanism by monitoring most of the national park areas in Johor. The DID manages all rivers and irrigation on the forested land and becomes an important agency in assisting the managing of water catchment areas. TCPDJ and DLMJ must work closely with each other in redrawing territories and update maps as per the land use changes. Local authorities, within their own legislative powers, must have CFS incorporated into their Local Plans. A simple monitoring networking in between FDPM and FDJ would further enhance the entire mechanism.

The State Secretariat of Johor is the most important agency in advising and providing directives to State Economic Planning Unit (EPUJ) when it pertains to development projects or major land use activities on its state lands. As indigenous settlements are important groups of people who still have a high dependency on forests, the Department of Indigenous Development plays an important role in creating awareness among them in conserving the forests and preserving the wildlife. The local authorities, according to the officers from Malaysian Nature Society and TRAFFIC International, if assigned power accorded to their jurisdiction, will be a great assistance in implementing CFS. PERHILITAN has been recreating the link between fragmented areas using viaducts, underpasses and tracks for wildlife movements with the assistance of PWD at identified areas and links which require them. The PWD is now incorporating the idea of wildlife crossings when building roads whereby newly built roads are likely to have channels for alternative wildlife crossing. In areas of affected or poor forest covers, FDPM agreed to carry out reforestation activities using timber tree and fruit trees. A pilot project was executed in Temerloh, Pahang by planting Acacia trees for erosion control and to attain a natural stand. Nevertheless, plans for arboreal animals such as squirrels and monkeys are lacking. This type of animals would require aerial lines across the roads or highways so that they will also be able to cross. Even though the complaints on disturbance of squirrels are relatively zero, there had been quite a number of complaints on the disturbance by monkeys. A number of NGOs, NPCJ and PERHILITANJ have been actively conducting awareness campaigns with regards to human-wildlife conflicts and wildlife conservation.

Various agencies work hand-in-hand in monitoring and providing maintenance in aspects which are under its responsibility and prerogative. However, these agencies are not close knitted and communication channels are unclear, causing a rough passing of information from one agency to another. Nonetheless, the relationship between two main agencies that are considered the forest experts: FDPM and PERHILITAN seem to be warm and cooperative, utilizing communication methods that is less complex with low number of bureaucratic processes. There also exists a 
boundary between federal and state agencies although they both operate at the local level. Constraints in achieving the integrated system is caused by the weak relationship between the various agencies as all the agencies work in silo to implement its responsibilities and maintains minimal communication with other agencies.

\section{CONCLUSION}

The analysis finds that over four years after CFS study was completed, there are instances where links have deteriorated. This can be proven by the primary link nearby Kampung Punan which is almost broken due to a pre-approved timber-latex clone project. The fast growing Iskandar Development Region as South Economic Corridor and the proposed East Coast Economic Region Rail project connecting the east coast cities, however, are not seen as threats as the development and its edge effect can be controlled and monitored. The factors that caused forest fragmentations in Johor are development, agricultural activity and land opening for other purposes. The occurrences of human-wildlife conflicts were higher due to land openings. Implementation of CFS is complicated due to inability to balance conflicts between development and conservation as well as generating income rather than allocating money for conservation activities. In Johor, the timber-latex clone plantation project was approved even before the passing of CFS which leaves the state government with no ability to reclaim the land as it would incur cost for replacement of land and other losses. Furthermore, land replaced may not be a suitable area to carry out the same project. The indigenous population, who still reside in villages, lack awareness in setting traps, capturing wildlife and expanding their living area in the forests. Kampung Tewowoh and Kampung Punan lies on the corridor of a herd of elephants. As population settlements expand, the people tend to use up extended land around the existing area which could cause human-wildlife conflicts. Funding and manpower remains an issue which applies to the State of Johor. FDPM has applied for external funding which currently fund projects and programs in six main areas; biodiversity, climate change, international waters, land degradation and persistent organic pollutants and ozone depletion. A National Steering Committee that comprises of MNRE as Chair, FDPM, PERHILITAN, DID, EPUJ from eight related states has been established. FDPM is responsible for all forest reserve covers under its jurisdiction while the PERHILITAN is in charge of wildlife. However, these two agencies have no authority to charge a person who has committed offence and require the assistance of the Royal Malaysian Police. Official integrated management plan at the state is absent as CFS is still at its infancy. With ongoing discussions and in-depth research, this administrative action is seen as a feasible option. However, accompanied by the current efforts and the ongoing discussions and planning activities, CFS is moving in a positive direction. Given more time, there will be tremendous improvements in the administration and management of CFS, as a whole. Even though the negotiation processes with the State governments may take some time, but with other options of revenue through ecotourism rebranding, CFS can be a successful tool in preserving the remaining forests and biodiversity that Malaysia holds.

\section{PROPOSALS FOR ADMINISTRATIVE ACTIONS}

There is no doubt that CFS is important to ensure biodiversity and sustainable environment. It is thus imperative that levels of government work closely to achieve this goal by putting aside political differences and needs. The existence of high level councils could be used as an effective tool. Administrative actions are important to ensure that the objective of conserving and preserving the biodiversity can be achieved in nearest future. As such, looking into methods that has been practiced in other countries as well as East Malaysia, the CFS should incorporate them in producing a management plan.

\section{A. Management Plan-Macro and Micro}

Management plans at both macro and micro levels should be established. This would be the most important key plan for both the federal and state level agencies in establishing the links between the forest islands. The management plan at macro level would incorporate all the agencies and their respective responsibilities to ensure CFS is managed accordingly. This management plan would be a document to have all agencies to have the same goal and aim in implementing CFS. Agencies at the federal level also would play the role of planning and coordinating which also includes the most important task of ensuring sufficient finances for its implementation of CFS through applying for funding from the Federal government as well as other international funding bodies. The implementation agencies at the State levels may then apply to the Federal level agencies to fund their activities or projects. Besides, the Federal agencies can also coordinate for commodities plantation businesses to abide by CFS by providing incentive schemes. Ministry of International Trade and Industries (MITI) should be roped in to create a system of recognition of CSR which could boost their businesses locally and internationally. The "Handbook: Economic Instruments for Environmental Management Malaysia" by Economic Planning Unit (EPU) (2004) could be used to establish an environmental rating system for business that deals with the natural resources and environment, not only by the plantation companies but also the manufacturers and logistics companies. This would create a win-win situation for the businesses, the government and the environmentalists. As for the management plan at the micro level, it is proposed that a specific management plan as to what will be done by each agency inclusive of all technical methods and steps are to be included. The management plan at micro level would ensure that all officers and personnel who are involved are provided with appropriate training. This multi-agency committee which would also be known as the State Technical Committee will be responsible in re-creating the links between the forest islands. The State should ensure that CFS is incorporated into its state and local plans. Any form of development or land use change should abide by the CFS after gazetting the document and the areas according to it to reduce any further destruction to both the primary and 
secondary forest links. Evaluation of EIAs should be made more stringent.

\section{B. Community Forestry Establishment and Legal Tenure}

Programs such as this have assisted many communities around the globe by allowing the communities to act as stewards or guardians to the forests near to their villages. In Cambodia, more than 150 sites have received pre-approval for now and a number of these sites have obtained a 15-year legal tenure. The program also supports mapping initiatives that delineate the area of community control, enabling more effective forest protection and reducing contentious encounters with competing interests.

\section{Forest Livelihoods Program}

Forest Livelihoods Program could also be a solution to maintain a balance between income and destruction. Programs such as this give local communities a control on the forest resources and encourage its distributions, avoid creating policies that has loopholes for forest destruction, employing conservation approaches so that forest dwellers do not lose access to their resources, raising the awareness of the importance of forests to local people. Programs such as the Center for International Forestry Research's (CIFOR) Livelihoods Program develop technologies, institutional mechanisms and policies to reduce the poverty of people.

\section{Ecotourism Rebranding}

As the idea of conservation and preservation may not be feasible especially when a country needs revenue, the idea of CFS can be rebranded as a product of the Ecotourism sector under Ministry of Tourism Malaysia (MOT). Currently, this suggestion is only applied by one agency which is Department of Wildlife and National Parks (PERHILITAN). However, CFS may receive more fund and manpower allocations if this idea can be elevated to the Ministry of Tourism (MOT) by the Ministry of Natural Resources and Environment and Department of Wildlife and Natural Parks.

\section{E. Sustainable Financing through REDD Forest Carbon}

REDD+, a global term for Reduce Emissions from Deforestation and forest Degradation is an initiative established to pay groups or countries for protecting their forests and reducing emissions of greenhouse gas pollutants, especially CO2. REDD+ is also concerned with much more than carbon, and could improve biodiversity, water quality, and other vital environmental services. And it could help ensure livelihood security and clear rights for local communities and indigenous peoples. It is currently a central topic of negotiations under the United Nations Framework Convention on Climate Change. With REDD+, wealthy countries could purchase carbon credits, often called "carbon offsets," from developing countries who keep their forests standing. Alternatively, REDD+ could be separated from the carbon credit market, so that wealthy countries would have to meet REDD+ commitments in addition to their own emission reductions. Through this, CFS could also generate finances to administer and manage the plan.

\section{F. GIS Mapping}

When information on trees is mapped into GIS System, agencies like Forest Department of Peninsular Malaysia can easily monitor illegal logging of trees. Likewise, forested areas can be monitored for wildlife movements. When deforestation decreases, human-wildlife conflicts also may decrease.

\section{G. Job Scope, Amending KPI and Monthly Report}

The job scope of the agencies can be amended whereby administration of CFS can be added into their respective KPIs. The Ministry of Natural Resources and Environment, as the chair, can be a body which monitors the KPIs twice a year and the National Auditors can be coordinated to evaluate their achievements.

\section{H. Integrated Portal}

Information from all agencies can be integrated into one portal whereby data can be obtained easily. However, there has always been a concern when it can cause more problems when information is accessible to the entire agency, especially information on wildlife. Furthermore, given this, it is foreseen that the poaching and illegal trades would rise.

\section{International Funding and International Recognition}

International funding such as the Global Environment Facility (GEF) and international recognition such as the UNESCO World Heritage Forest (WHF) would certainly be a good boost to ensure that this plan is adhered to accordingly. Currently, GEF allocates a total of US $\$ 1.6$ billion on its own besides another US $\$ 5$ billion leveraged from other sources. A total of 104 sites have been identified by United Nations in conjunction with the International Year of Forest in 2011.

\section{REFERENCES}

[1] FAO, Main Report: Global Forest Resources Assessment 2000, Forestry Paper, vol. 140, pp. 479, 2000.

[2] E. J. Bosi and S. Siburat, "SOS Rhino (Borneo) and Sabahmas Plantation-partners in conservation," paper presented at Session 3Paper 8 - PPB Oil Palms Bhd, 2009.

[3] C. Yong, Forest Governance in Malaysia: An NGO Perspective, FERN, 2006.

[4] Department of Statistics Malaysia, Yearbook of Statistics, Malaysia, Kuala Lumpur: Government Printers, 2010.

[5] G. Meffe and C. Carroll, Principles of Conservation Biology, Sinauer Associates, Massachusetts: Sunderland, 1997.

[6] The Star (2009a), Broken Spine, 31 March 2009.

[7] Ministry of Housing and Local Government Malaysia, Buletin Perangkaan Perumahan 2000, Kuala Lumpur: Percetakan Nasional Berhad, 2010.

[8] M. I. Hasmadi, M. S. Alias, and K. Norizah, "Reclassifying forest type to a new forest class based on vegetation and lithology characteristics using geographic information system at Southern Johore, Malaysia," International Journal of Energy and Environment, vol. 4, no. 2, pp. 171-178, 2008.

[9] E. Brown and M. F. Jacobson, Cruel Oil: How Palm Oil Harms Health, Rainforest and Wildlife, Washington: Center for Science in the Public Interest, 2005.

[10] T. V. Vilarrubia, M. Maass, V. Rull, V. Elias, A. Ramon, C. Ovalle, D. Lopez, G. Schneider, P. J. Depetris, and I. Douglas, "Small catchment studies in the tropical zone," in Biogeochemistry of Small Catchments: A Tool for Environmental Research, C. J. Moldan, Ed. John Wiley, Chichester, 1994.

[11] Malaysian Timber Council, Malaysia Sustainable Forest Management, Kuala Lumpur: Malaysian Timber Council, 2007.

[12] TRAFFIC International, Progress Report on the Study on Forest Law Enforcement and Governance in Malaysia in the Context of Sustainable Forest Management, International Tropical Timber Council, ITTC (XXXVI)/8, 30 June, 2004. 
[13] Ministry of Natural Resources and Environment Malaysia, Response to the Article, 10th, 12th and 13th August 2009, Kuala Lumpur: Ministry of Natural Resources and Environment, 2009.

[14] W. C. Woon and H. Norini, Trends in Malaysian Forest Policy, Policy Trend Report, 2002, pp. 12-28.

[15] K. S. Jomo, Y. T. Chang, and K. J. Khoo, Deforesting Malaysia - The Political Economy and Social Ecology of Agricultural Expansion and Commercial Logging, London and Geneva: Zed Books and UNRISD, 2004.

[16] J. H. Drabble, An Economic History of Malaysia, c. 1800-1990: The Transition to Modern Economic Growth, Houndmills, Basingstoke, Hampshire: Macmillan Press Ltd, 2000.

[17] C. H. Teoh, Land Use and the Oil Palm Industry in Malaysia, Abridged report produced for the WWF Forest Information System Database, 2000.

[18] Malaysian Palm Oil Board (MPOB), Malaysian Oil Palm Statistics 2010, Kuala Lumpur: Malaysian Palm Oil Board, 2010

[19] Malaysian Palm Oil Council, Malaysian Palm Oil Wildlife Conservation Fund (MPOWCF), Kuala Lumpur: Malaysian Palm Oil Council, 2006.

[20] M. W. Basri, I. Maizura, A. S. N. Akmar, and K. Norman, "Oil palm," in Handbook of Industrial Crops, V. L. Chopra and K. V. Peter, Eds. New York: The Haworth Press, 2003.

[21] Earth Observation Centre of Universiti Kebangsaan Malaysia, Land Use and Land Cover Change for Southeast Asia Malaysian Case Study, Asia Pacific Network for Global Change Research (APN), 2001.

[22] Department of Wildlife and National Parks of Peninsular Malaysia, National Tiger Action Plan for Malaysia 2008-2010, Kuala Lumpur: Government Printers, 2008
[23] Jabatan Perancang Bandar dan Desa Semenanjung Malaysia, Laporan Akhir Central Forest Spine: Pelan Induk Rangkaian Ekologi, Kuala Lumpur: Town and Country Planning Department Malaysia, 2010.

[24] Utusan Melayu, Pulihara Kelestarian Alam Semulajadi, 14 July 2011.

[25] Johor State Forestry Department, Summary of the State of Johor Forest Management Plan for the Period between 2006-2015, Johor: Johor State Forestry Department, 2006.

[26] The Star (2009b), Wildlife under Threat, 31 March 2009.

[27] M. Musa, "The socioeconomic history of the Orang Kanaq of Johor," Kajian Malaysia, vol. 29, no. 1, pp. 47-74, 2011.

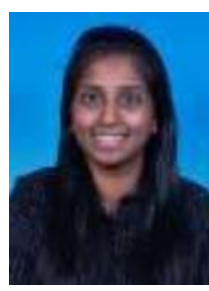

Agkillah Maniam graduated with a bachelor of forestry science from University Putra Malaysia (UPM), Serdang, Selangor in 2009 and attained her Master of Public Administration from University of Malaya (UM), Kuala Lumpur in 2012. She is currently pursuing her $\mathrm{PhD}$ in Political Science in University of Auckland, New Zealand. She currently serves as a fellow in the Department of Administrative Studies and Politics, Faculty of Economics and Administration, University of Malaya. Prior to this, Agkillah has served as a research officer in University of Malaya and worked in a number of market research companies such as Taylor Nelson Sofres and The Nielsen Company, obtaining all-rounder skills of both academic and corporate research. 